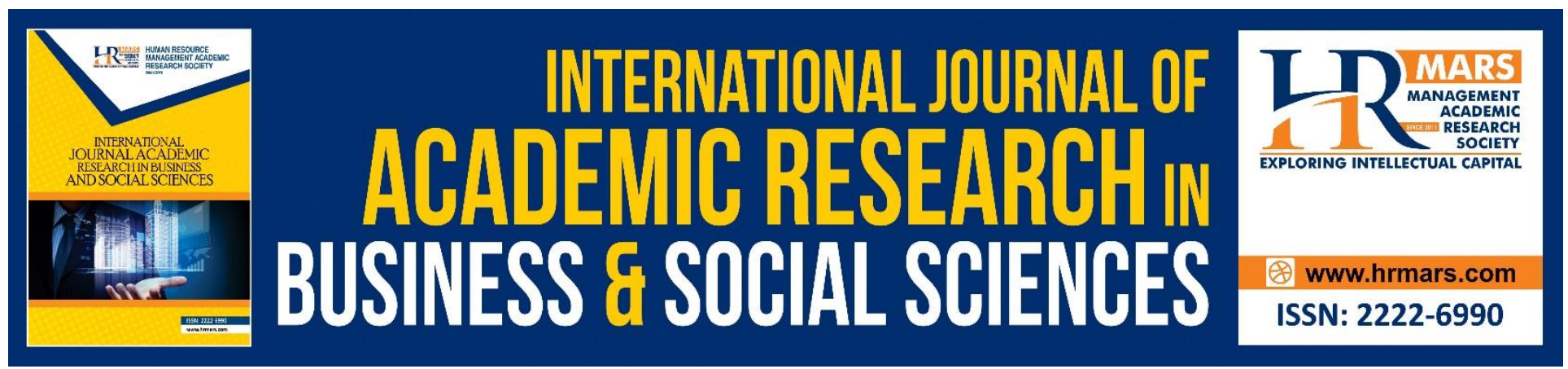

\title{
The Abhorrent Character in Development Actor: An Analysis Based on the selected Parable (Tamthiliyyat) in Al-Qur'an
}

Nurul Farhana Yahaya \& Mohd Shukri Hanapi

To Link this Article: http://dx.doi.org/10.6007/IJARBSS/v8-i10/4719

DOI: $10.6007 /$ IJARBSS/v8-i10/4719

Received: 23 Sept 2018, Revised: 11 Oct 2018, Accepted: 16 Oct 2018

Published Online: 30 October 2018

In-Text Citation: (Yahaya \& Hanapi, 2018)

To Cite this Article: Yahaya, N. F., \& Hanapi, M. S. (2018). The Abhorrent Character in Development Actor: An Analysis Based on the selected Parable (Tamthiliyyat) in Al-Qur'an. International Journal of Academic Research in Business and Social Sciences, 8(10), 126-134.

Copyright: (C) 2018 The Author(s)

Published by Human Resource Management Academic Research Society (www.hrmars.com)

This article is published under the Creative Commons Attribution (CC BY 4.0) license. Anyone may reproduce, distribute, translate and create derivative works of this article (for both commercial and non-commercial purposes), subject to full attribution to the original publication and authors. The full terms of this license may be seen at: http://creativecommons.org/licences/by/4.0/legalcode

Vol. 8, No. 10, 2018, Pg. 126 - 134

http://hrmars.com/index.php/pages/detail/IJARBSS

JOURNAL HOMEPAGE

Full Terms \& Conditions of access and use can be found at http://hrmars.com/index.php/pages/detail/publication-ethics 


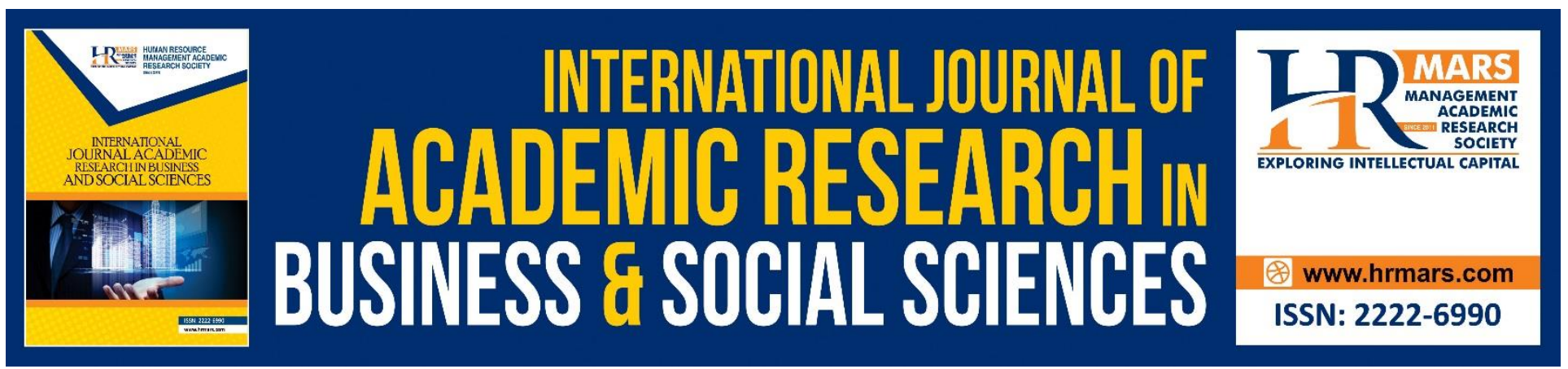

\title{
The Abhorrent Character in Development Actor: An Analysis Based on the selected Parable (Tamthiliyyat) in Al-Qur'an
}

\author{
Nurul Farhana Yahaya ${ }^{1} \&$ Mohd Shukri Hanapi $^{2}$ \\ ${ }^{1,2}$ Centre for Islamic Development Management Sudies (ISDEV), University Sains Malaysia, 11800 \\ Minden, Penang, Malaysia.
}

\begin{abstract}
The parable (tamthiliyyat) is one of the style (uslub) in al-Qur'an. The tamthiliyyat elements in alQur'an are the verses (ayah) that have a similiarity between one to the others. They have a lot of aims and objectives such as to give some lessons and educate the mankind. So, the mankind is a main entity as the actor wheter in the conventional development and the Islamic development. But, their different functions will make the character also will be different to. In al-Qur'an, the human as the actor also potray their own type of tamthiliyyat that are the good (mahmudah) characters and the mazmumah characters. The questions are first, what are the verses (ayah) of the representation that contained in al-Qur'an? Second, how these actors are represented in the form of tamthiliyyat in alQur'an? In order to answer both questions, this paper will have two main objectives. First, to find out the tamthiliyyat that contained in the verses (ayah) of al-Qur'an in form of the mazmumah character of the actors in al-Qur'an and second, to analyse the character of the actors in that verses (ayah). This research is using the thematic methodology of the commentaries of al-Qur'an (tafsir al-Qur'an). Among the findings are the tamthiliyyat of a dog to represent a greediness for the sake of him or herself. Besides that, there is also tamthiliyyat of a donkey that refer to those who take for granted towards the commands of Allah Almighty but actually they knew them. All the mazmumah character must to be avoid in order to get Allah's blessings.
\end{abstract}

Keywords: Character, Development Actor, Tamthiliyyat Mazmumah.

\section{Introduction}

All the development there will be their development actors. In the Islamic-based development, all the actors are the mankind itself. But, the human as the actors in the conventional development is different with the Islamic one. In the conventional development, the human as an economic creation who are only be the producer and consumer. Whether in the Islamic-based development, human as a servant and caliph of Allah the Almighty. As the functions are very different in the both aspects, so 
certainly the character also might be different. In al-Qur'an, these character are being described in an unique way that is in a form representation. As a human, we believe that we can have good character (mahmudah) that must to be practiced and abhorrent character (mazmumah) that must to be avoided. However, this study only will discuss about the abhorrent character (mazmumah).

Because of that issue, this study to achieve two main objectives. First, identify the verses that contain the tamthiliyyat in term of mazmumah character for the human mentioned in al-Qur'an; and second, analyzing the character development of the human in the verses of the identified tamthiliyyat. To achieve these both objectives, the discussion in this paper is divided into three main parts. First, the discussion on the concept of tamthiliyyat. Second, the discuss on the human character in conventional development. Thirdly, the discusses regarding the human character in the development of Islam. Finally, analyzing the abhorrent parable (tamthiliyyat mazmumah) character for the mentioned in al-Qur'an.

\section{The Concepts of Tamthiliyyat}

Tamthiliyyat means the something that is representing something other with clear words, simple, compact and full of wisdom to be accepted and understood. In term of language, it comes from the Arabic word which is the plural of the word mathal, mithil mathil, which have the same meaning with syabah, syibh and syabih which means the same, similar, like and as such as (Ibrahim, 1985). According to IbnManzur (1955), tamthiliyyat ia something that being compared to something that is very close to it. In addition, it is also said in other word such as signs and teaching.

Al-Qattan (1973) says that tamthiliyyat in al-Qur'an not only simply meaning which is something that have the same meaning. It also included the arrangement of the verse that can give some meaning to potray its meaning as well as an interesting, simple and compact overview.

The definition of the tamthiliyyat came with a variety of meanings based on its own field. According to its terminology, the Arabic literature scholars interpret amthal as the word that have similarities with something specifically. In addition, according to 'ilm bayan's scholars, the tamthiliyyat is an expression of majaz because of the availability of tasybih. Hence, it must fulfill several aspects, namely, simple phrase with exact meaning, the good tamthiliyyah and beautiful kinayah. Next, according to the al-Quran commentaries' (tafsir) scholars, amthal is displaying sense of abstract in a beautiful, short phrases and interesting to soul, both in the form of tasybih or majaz mursal (Muhammad, 2013).

The opinion of Abu Hilal al-Askariy on the other hand, mathal contains secret and wisdom behind the words. In addition, relating something with something else according to their condition and nearing the meaning of something abstract (ma'qul) with something concrete (mahsus), or put two concrete with others and assume that one of them as the other (put similarity) (IbnQayyim, 1981). 
Therefore, the meaning of mathal or tamthiliyyat in this research paper refer to parables in al-Qur'an that are related with humans. It also covers tamthiliyyat from the natural elements and the animals that have connections with humans. However, the tamthiliyyat related to animals that potrey the mazmumah character will be focused in this paper.

\section{Human Character in the Conventional Development}

The human being is an important aspect in the context of the development of the conventional and Islamic because human beings are involved directly in the development agenda. However, in the conventional development of man is always act as the 'economic man' when their social task is to increase profits simply by using all energy to achieve their desires (Umer, 2001).

Karl Marx, a scholar from the West once mentioned about the human aspect as the actor of the development in the concept of labor power which is the workers need to sweat for blushing fulfil the employer (Rahman, 2006). The capacity and expertise of the workers who became standard in assessing the qualities of a person. Such a thing had been planted within the framework of thought conventional in assessing the qualities of a man as the perpetrator of the development. The conventional Development also see human with the levels that they will give in return to a investment in an organization. Thus, the physical advantages possessed by a man will give a great return than the other human beings.

In addition, the conventional development also see man as a capital that needed to be invested for the benefit of an employer. This has been highlighted by Fauzi (2012) that there are four main characters who pioneered the field of human development which was Adam Smith, H. Von Thunen, Irving Fisher and Alfred Marshall, which stated that humans as capital in order to seek wealth and profits solely. For example, Adam Smith (1723-1790) is a prominent economic philosopher that incorporates human beings who have the potential and ability to be used as capital for acquire wealth to the country. Here it can be seen that the human factor is essential for achieving profitability and wealth.

Therefore, it can be concluded that human development in perspective as the perpetrator in conventional development just only look for the physical capabilities and skills that will provide opportunities and rewards in the aspects of economic development only. The more the human potential in contributing to the development, then the man will be rewarded for good despite have to give their entire energy to fullfill the needs of production and profit itself.

\section{The Human Personality In The Islamic-Based Development}

Human as an entity for development was given responsibility by Allah, blessed with mind and glorified by Him (Muhsin, 1998). In this case, the intellect, spirit and physical given by Allah to human in order to manage this world. Thus, human was urged to pursue knowledge as a preparation for starting the development. It is also because men have been approved by Allah that man is the most nobled creations (asyraf al-makhluqat) and the best creations (ahsan al-khaliqin) (Jalil, 2007). 
The character of mankind as the perpetrator of the Islamic-based development is also thus shaped through the functions that are run by them which is as a servant and caliphs of Allah. Human in this type of development is seen to have a clear aim to the end of development and life which is to get His blessing and attempting to obtain a substantial triumph (al-falah) (Aidit, 1990 \& Rahman, 2006). In addition, in the context of dealing with natural resources that exist, this man very well and keep the mandate to deal with resource with full dedication (Kasim, 2008). Furthermore, the main character of being good for mankind as the perpetrator of this development is the firm tauhid believe in the planinnig of the development actions.

\section{Analysing the Abhorrent (Mazmunah) Character for the Development Actor in the Tamthiliyyat Al- Qur'an}

The character of the development actor in the conventional development and the Islamic one is based on human functions itself. The function of the human will form the human character itself as the actor of development. In the conventional development, human function just simply as producers and consumers to reach the stage of progress in life and run a function that is both stereotype and circularity as user, grown up, study, work, getting family, reproductive and finally died. Then, this type of trait will be more concerned to the material and the sublimity of the lust for profit and progress reached the stage in life. They also ignored the prohibition from Allah the Almighty and the rights of the other human beings. In addition, the values of religion and divinity are also ignored by them and it was placed outside the development activities. They only have links to their fellow human beings and nature without being associated with a link with Allah the Almighty.

However, the matter is quite different from the human personality based on the al-Qur'an. Of human personality based on the Qur'an is also composed from the human functions in the development in Islamic ways. This type of human has two main functions based on their vertical relationship with Allah the Almighty ( $\mathrm{habl}$ min Allah) as a servant of His, while horizontal relations with human and natural resources as (habl min al-nas) with the title of His caliph.

In this regard, human traits can be seen through the tamthiliyyat contained in the al-Qur'an. These traits can be divided into two categories namely mahmudah (good) and mazmumah (abhorrent). However, this paper is limited and just only dicuss the mazmumah one from the verses of al-Quran to be analyse.

Table 1: The Character of Development Actor in Tamthiliyyat al-Quran

\begin{tabular}{|c|l|l|}
\hline Theme & \multicolumn{1}{|c|}{ Ayah } & \multicolumn{1}{c|}{ Tamthiliyyat for the Character } \\
\hline Mazmumah & al-Jumu'ah, 62:5 & Donkey \\
& al-'Araf, 7:176 & Dog \\
& al-'Araf, 7:179 & Beast \\
& al-Ankabut, 29:41 & Spider \\
\hline
\end{tabular}

The mazmumah character can be seen where there is some animal was used to show the mazmumah character that are the donkey, dog, beast and spider. 


\section{Tamthiliyyat of The Donkey}

This can be seen as Allah once said:

"The similitude of those who were charged with the (obligations of the) Mosaic Law, but who subsequently failed in those (obligations), is that of a donkey which carries huge tomes (but understands them not). Evil is the similitude of people who falsify the Signs of Allah. and Allah guides not people who do wrong" (al-Jumu'ah 62:5).

According to al-Zamakhshari (n.d), the Jews read and memorize the contents of the Torah but they do not and cannot take advantage of such revelations, hence they are not believing with the messenger even our Prophet SAW although his prophecy was enshrined in the Torah. Therefore, they were similitude with a donkey that carry a great scriptures on his back but it can't take advantage of the scriptures, on the other hand it just feel tired and fatigued only.

In the context of the development actor, it was seen such a useless thing if someone who has given knowledge, but he doesn't practice it in fact his action also show that he doesn't have the knowledge. Thus, there is no need for the perpetrators of the development to have this kind of trait.

\section{Tamthiliyyat of the Dog}

In al-Qur'an there is some type of animal characteristics found in man that is a dog. This mazmumah personality or trait that associated with dog because the dog is very humble and loyal to anyone who gives it eating and drinking, even though he is a bad person. People who potray this dog's characteristic do not want to submit to the verses of al-Qur'an, driven or not it will show its tongue. As Allah once said:

"If it had been Our will, We should have elevated him with Our signs; but he inclined to the earth, and followed his own vain desires. His similitude is that of a dog: if you attack him, he lolls out his tongue, or if you leave him alone, he (still) lolls out his tongue. That is the similitude of those who reject Our signs; So relate the story; perchance they may reflect" (al-A'raf, 7:176).

Besides that, Rasulullah SAW also said:

"There is no any worse similitude than the similitude of a person who take what that he gave (present) just like a dog that lick again its vomiting" (Reported by al-Nasaie)

Thus, this character is very dangerous. This is because the guidelines and policies of human life is as a slave and caliph of Allah is al-Qur'an. When the humans have this kind of trait, they will bow and obey other things besides Allah. 
INTERNATIONAL JOURNAL OF ACADEMIC RESEARCH IN BUSINESS AND SOCIAL SCIENCES

Vol. 8, No. 10, Oct. 2018, E-ISSN: 2222-6990 ㄷ 2018 HRMARS

\section{Tamthiliyyat of the Beast (al-An'am)}

The most mankind who are put in the hell due to their mind and their feelings do not be used to understanding of oneness and the greatness of Allah. While that belief will cleanse their souls from all sound defiant and disgrace.

Many people claimed to believe in Allah, but actually they do not believe in the Hereafter. They just use their mind to gain the worldly gains without looking to the Hereafter in every action. As Allah said which means:

"They know but the outer (things) in the life of this world: but of the End of things they are heedless" (al-Rum, 30:7).

Mankind does not understand that the main purpose of this live is to worship Him and invest as much as they can for the Hereafter as a preparation. They are not aware that the purpose why Allah ordered them to avoid the sin and doing the charity is for getting two happiness-the world and the hereafter. But, they turn a blind eye, heart and ears with all sorts of guidlines that come to them. This is in line with the word of Allah which means:

"Many are the Jinns and men we have made for Hell: They have hearts wherewith they understand not, eyes wherewith they see not, and ears wherewith they hear not. They are like cattle,- nay more misguided: for they are heedless (of warning)" (al-A'raf, 7: 179).

In the context of development, human kind as actor need to avoid this character such as these beast animals. Allah bless human with minds and the five senses to be used in understanding the verses of Allah which is a guideline for human life. It coincides with the function of the human being as the perpetrators based on the Islamic development.

\section{Tamthiliyyat of the Spider}

Those who seeking protection to other than Allah just like a spider because it is hedging himself with buildings that it thought to be sophisticated, even there are who protect themselve with Satan with magic spells, charms other than Allah.

It is related to what Allah has said:

"The parable of those who take protectors other than Allah is that of the spider, who builds (to itself) a house; but truly the flimsiest of houses is the spider's house; - if they but knew" (al-Ankabut, 29:41).

Humans who seek protection other than Allah use it in order to get power, benefit and safetiness. They seek them from the things such as inanimate objects (sacred metal, stones, etc.), large object (mountain, lightning, the Sun, and so on), animals, humans and Jinn. 
INTERNATIONAL JOURNAL OF ACADEMIC RESEARCH IN BUSINESS AND SOCIAL SCIENCES

Vol. 8, No. 10, Oct. 2018, E-ISSN: 2222-6990 @ 2018 HRMARS

They forget that everything in the universe is always praising, bowing only to Allah, the most rich. It is a futile and useless action when taking other as protector without truly believe to Allah.

\section{Conclusion}

The character of human is the application from the function played by them in the Islamic-based development which is as a servant of Allah the Almighty and His caliph. However, the function of human beings in the conventional development form their characters to only run the role as consumer and producer for achieving profits. The character of human beings based on this parable (tamthiliyyat) of al-Qur'an only focused on the abhorrent parable (mazmumah tamthiliyyat) that included the discussion of the parable (tamthiliyyat) of the donkey, the dog, beast and the spider.

\section{Corresponding Author}

Nurul Farhana Yahaya, Centre for Islamic Development Management Studies (ISDEV), University Sains Malaysia, 11800 Minden, Penang, Malaysia, Email: nfymfa89@gmail.com.

\section{References}

Aziz, Y. A. (2012). Pembangunan Holistik Dari Perspektif Islam. Kuala Lumpur: Dewan Bahasa dan Pustaka.

Jalil, A. B. (2008). Asas pembangunan modal insan. Pahang: Penerbit Universiti Malaysia Pahang.

Abdul Rahman, A. (2006). Pembangunan modal insan: apa dan kenapa perlu dalam konteks organisasi di Malaysia. Kuala Lumpur: Human Resources Academy.

Ahmad, M. S. (2007). "Pembangunan Modal Insan: Konsep, Perkembangan, Cabaran dan Implikasi", in Khalidah, S. \& Ahmad, M. S. (Ed), Pembangunan Insan: Aspirasi dan Realiti. Selangor: Kolej Dar al-Hikmah.

Aidit, G. (1990). Development an Islamic Perspective. Selangor: Pelanduk Publications.

IbnQayyim, A. (1981). Al-Amthal Fi al-Qur'an al-Karim. Lubnan: Dar al-Ma'rifah.

Al-Khalidiy, S. A. A. (2001). Al-Tafsir al-Mawdu'iy Bayn al-Nazariyyat wa al-Tatbiq Dirasat Nazariyyat wa Tatbiqiyyat Murafaqat bi Namazij wa Lata'if al-Tafsir. 'Amman, Jordan: Dar al-Nafa'is

Al-Qattan, M. K. (1973). Studi Ilmu-Ilmu al-Qur'an, trans. by Mudzakir. Jakarta: Pustaka Litera.

Al-Zamakhshari, M. A. (t.th). Tafsir al-Kashshaf 'an Haqaiq Ghawamid al-Tanzil. Beirut: Dar al-Kitab al-Arabi.

Azhar, M. (2008). Perumpamaan al-Qur'an. Johor: Universiti Teknologi Malaysia.

IbnManzur, A. A. J. A. M. (1990). Lisan al-'Arab. Beirut: Dar al-Sadir.

Ishak, Y. \& Zulkifly, O. (2008). "Pembangunan Modal Insan di Malaysia: Perspektif Ekonomi", in Yahaya, I. (eds), Pembangunan Modal Insan Isu dan Cabaran. Bangi: Universiti Kebangsaan Malaysia.

Kasim, M. (2009). Pembentukan Modal Insan Cemerlang: Pendekatan Ekonomi Islam. Sabah: Universiti Malaysia Sabah.

Mahmud, M. B. (1988). Ekonomi Dari Kacamata Islam, transl. by Ismail Mohd Hassan. Terengganu: Yayasan Islam Terengganu.

Michael, P. T. (1978). Economic Development in the Third World: An Introduction to the problems and policies in a global perspectives. London and New York: Longman. 
INTERNATIONAL JOURNAL OF ACADEMIC RESEARCH IN BUSINESS AND SOCIAL SCIENCES

Vol. 8, No. 10, Oct. 2018, E-ISSN: 2222-6990 @ 2018 HRMARS

Fauzi, M. H (2012). Tinjauan Kepentingan Pembangunan Modal Insan di Malaysia. Jurnal al-Tamadun. Bil. 7(1) 2012, 75-89. Kuala Lumpur: Akademi Pengajian Islam, Universiti Malaya.

Hanapi, M.S. (2014). Tasawur Islam dan Pembangunan. Kuala Lumpur: Dewan Bahasa dan Pustaka.

Muhammad, A. (2013). Fungsi Perumpamaan dalam al-Qur'an. Jurnal Tarbawiya. Vol. 10, Number. 2 , 2013.

Kamal, H. (1990). “Pembangunan Yang Berteraskan Islam”, in Muhammad Syukri, S. (ed.), Konsep dan Pelaksanaan Pembangunan Berteraskan Islam. Penang: Universiti Sains Malaysia.

Syukri, M.S. (1990). "Pembangunan Untuk Manusia Atau Manusia Untuk Pembangunan: Analisis Tentang Manusia dalam Pembangunan Berteraskan Islam", in Muhammad Syukri, S. (ed.), Konsep dan pelaksanaan pembangunan berteraskan Islam. Penang: Universiti Sains Malaysia.

Syukri, M.S. (2003). 7 Prinsip Pembangunan Berteraskan Islam. Kuala Lumpur: Zebra Editions Sdn. Bhd.

Muhsin, A. H. (1998). Islam dan Pembangunan Sosial. Selangor: Thinker's Library Sdn. Bhd.

Mustafa, M. J. (1986). "Konsep Manusia dari Perspektif Barat dan Islam”, in Hashim \& Mahayudin, Y. (Eds), Sains Sosial dari Perspektif Islam. Bangi: Universiti Kebangsaan Malaysia.

Rahmah, I. (1996). Modal Manusia dan Perolehan Buruh. Kuala Lumpur: Dewan Bahasa dan Pustaka. Sarizah, S. \& Nazri, Z. (2005). Asas-asas Ekonomi. Pahang: PTS Profesional

Shahnon, A. (1990). "Fungsi dan Peranan Islam Dalam Pembangunan Ummah: Antara Harapan dan Kenyatan", in Muhammad Syukri, S. (ed.), Konsep dan Pelaksanaan Pembangunan Berteraskan Islam. Penang: Universiti Sains Malaysia.

Surtahman, K. H. \& Sanep, A. (2005). Ekonomi Islam. Kuala Lumpur: Dewan Bahasa dan Pustaka. Husin, A. (1976). Apa Erti Pembangunan. Kuala Lumpur: Dewan Bahasa dan Pustaka.

Umer, C. (2001). Masa Depan IImu Ekonomi Sebuah Tinjauan Islam. Jakarta: Gema Insani Press. Willis, K. (2005). Theories and Practices of Development. London: Routledge Taylor \& Francis Group. 